\title{
Peter K. Christoff, 1911-1998
}

Peter K. Christoff, a world-renowned expert on Slavophilism, died on 3 January 1998. Born in Sophia, Bulgaria, in 1911, Christoff attended American College in the city of his birth and completed his undergraduate studies at Oberlin College. In 1938, after earning an M.A. degree from Brown University, he began working toward a doctorate in history, completing all requirements, except the dissertation, before World War II. After serving in the American military forces in World War II (1943-45), he returned to Brown University and completed his doctoral dissertation. In his work on the dissertation, he benefited from valuable counsel and exchange of ideas with George Vernadsky, professor of Russian History at Yale University. In 1947, a research grant from the Hoover Institution enabled him to lay the groundwork for his lifelong scholarly pursuit: a study of the inner complexity, influence, and intellectual foundations of the Slavophile movement.

In 1950 Christoff joined the faculty of San Francisco State University, where he stayed until his retirement in 1977. In two separate academic years he was a visiting professor at Leiden University in Holland. As a visiting professor, he also taught at Stanford University and Mills College. A dedicated and enthusiastic teacher, Christoff crafted lectures that were rich in organized material, precise in logical structure, and incisive in historical perspective. A subtle sense of humor gave his lectures a natural flow and appealing vivacity. He considered teaching a key component of his profession and a task that was both demanding and richly rewarding.

Christoff and Nancy Patterson were married in 1948. He is survived by Nancy and by his son, Alec; daughters, Ann Weiss and Kathy; and grandsons, Alexander and Christopher. The family was Peter's haven, generating happiness, peace of mind, healthy pride, and ideal conditions for combining professional duties with enjoyable hobbies. As a young man he earned a medal in track in the Balkan Olympics held in Athens. Later in life, gardening was his main hobby. With Nancy's time-spacing of colorful bulbs that produced the most impressive sequences of flowers and his tender care of fruit trees, they transformed their backyard into a veritable botanical garden. His trees produced almonds, figs, quinces, plums, and oranges that compared favorably with the best in his part of California.

Four monumental biographies constitute the main and most noted product of Christoff's historical scholarship: A. S. Xomjakov (1961), I. V. Kireevskij (1972), K. S. Aksakov: A Study in Ideas (1981), and Iu. F. Samarin (1991). Although the four men covered in these studies shared a general philosophical-ideological orientation, each reflected a unique temperament, life experience, professional involvement, educational background, and political impulse. Khomiakov's thinking gravitated toward the social implications of Russian Christianity, Kireevskii explored the area where epistemology and sociology intersected, Aksakov probed the mystical involvement of a branch of Russian philosophy, and Samarin dwelt more deeply on the burning questions of the Russian peasantry than any other Slavophile and articulated the Slavophile opposition to western "science materialism." Christoff's patience and remarkable erudition helped him to take a close look at the intricate web of Slavophile influence on Russian belles lettres, economic history, political dynamics, religious behavior, and thorny questions of philology. In his retirement, he gave much thought to the residues of Slavophile ideology in the works of such Russian literary masters as Fedor Dos. toevskii and such leading philosophers as Vladimir Solov'ev.

Beyond the diversity of individual concerns and backgrounds there was a strong unifying thread through the entire structure of Slavophilism. Christoff elucidated the overarching principle of Slavophilism: Russia could contribute to the progress of humanity, not by passing retreaded ideas borrowed from the west, but by building on the pure social forms and cultural values created by long stretches of its own history. Slavic Review 57, no. 1 (Spring 1998) 
In making an inventory of these forms and norms, Christoff paid particular attention to obshchina, sobornost', and the nascent purity of religious beliefs and behavior. 'The Slavophiles, as Christoff saw them, accorded primacy to faith over reason. His articles on Khomiakov and Kireevskii in The Encyclopedia of Philosophy summed up the main principles of the Slavophile world outlook.

In addition to his work on Slavophilism, Christoff published two general studies on the intellectual fermentation in Russia during the first four decades of the nineteenth century: The Third Heart: Some Intellectual-Ideological Currents in Russia: $1800-1830(1970)$ and "La renaissance culturelle russe des années 1830 et 1840" (in Histoire de la littérature russe, 1996). These publications concentrated on the ideological turbulence in Russia caused by the increasing contact with the west. Conditions leading to a rising conflict between Slavophilism and westernism provided the central topic of these studies.

Christoff's historical studies are based not only on a careful and competent reading of primary and secondary sources but also on a profound awareness of the currents of thought carrying broader philosophical and sociological messages.

Alexander Vucinicil Berkeley, California January 1998

\section{Donald Carlisle, 1935-1997}

Donald Carlisle, associate professor of political science at Boston College and an associate and fellow at the former Harvard University Russian Research Center (now known as the Davis Center for Russian Studies), died on Monday, 8 December 1997 at 2:30 in the afternoon. After fighting cancer for about a year, he finally succumbed to a heart attack. Many students and faculty throughout the world, especially those in Russian area studies within the fields of political science and Uzbek studies, mourn his passing. At Boston College where Carlisle taught for almost thirty years, he was an energetic, lively lecturer and a very popular teacher, though he was known locally as "Killer Carlisle" because of his tough grading.

Carlisle rose from working-class conditions in New Haven, Connecticut, where he was born on 11 September 1935. He received his undergraduate degree summa cum laude from Brown University in 1958 and his Ph.D. from Harvard University in 1962.

Carlisle taught at the University of Wisconsin at Madison from 1962 until 1967, at the University of Toronto from 1967 to 1968, and at Boston College from 1968 until his death. He had been the associate director of the Russian and East European Center at Boston College since 1968, and the executive director of the Balkan Studies Project at Boston College since 1994. In 1984 he was visiting professor at Columbia University, and from 1985 to 1986 he served as president of the New England Slavic Association. At Boston College he regularly taught courses on Soviet politics, art, and civilization, and he team-taught courses on the Balkans with historian Raymond McNally. In addition, he developed expertise in the study of Central Asia, in general, and Uzbekistan, in particular. The United Nations Development Programme (UNDP) selected Carlisle to be a consultant and member of the UNDP delegation to Tashkent and Uzbekistan (27 October to 11 November 1992), a member of the UNDP delegation to Dushambe, Tajikistan (19 September 1993), analyst of the Management School Program in Kyrgyzstan for two weeks, and a member of a two-month mission to all five Central Asian countries to plan a regional conference (August-September 1994). He was invited to Uzbekistan by the president, Islam Karimov, for consultations in July 1995, and he was recently honored at the Harvard University Faculty Club for his work on Uzbek studies. He read and spoke Russian, German, and Uzbek.

Carlisle's interest ranged beyond those of the ordinary political scientist; he de- 